\title{
Containing Zika while we wait for a vaccine
}

\author{
Develop point-of-care diagnostics to target behavior change and prevent spread
}

\author{
Ranu S Dhillon doctor ${ }^{1}$, Devabhaktuni Srikrishna founder ${ }^{2}$, Ashish K Jha director ${ }^{3}$ \\ 'Division of Global Health Equity, Brigham and Women's Hospital and Harvard Medical School Boston, MA, USA; ${ }^{2} P a t i e n t$ KnowHow San Mateo, \\ CA, USA; ${ }^{3}$ Harvard Institute for Global Health, Boston, MA, USA
}

\begin{abstract}
Though no longer considered an emergency by the World Health Organization, Zika virus has reached over 70 countries and continues to spread. ${ }^{1}$ As long as each infected person infects, on average, at least one other person, the pandemic will grow. In highly affected areas, widespread infection and herd immunity could ultimately stall transmission but only after devastating consequences for new babies. ${ }^{2}$ Efforts to develop a vaccine seem promising, but it remains at least months away. ${ }^{3-7}$ In the interim, measures to eliminate mosquitoes, such as aerial spraying, cannot be effectively applied across over 70 countries. Other approaches are needed to stem transmission.
\end{abstract}

Eliminating mosquitoes is absolutely necessary only if there is substantial vertical transmission from mosquitoes to their offspring. For Zika, this is rare $(1 \text { in 290 })^{8}$ and insignificant compared with human mediated spread through mosquitoes and sex. About $80 \%$ of infected people are asymptomatic and therefore unaware they are propagating transmission. This "invisible" spread makes it difficult to know Zika's true transmission rate-estimates range from 1.4 to 6.6 new infections per infected person. ${ }^{9}$

Vaccines can block this transmission, but control is still possible without one. For example, malaria was eradicated in Sri Lanka by rapidly diagnosing and treating infected individuals and protecting those at risk. ${ }^{10}$ We can similarly curb Zika using voluntary screening in areas of known transmission to identify infected people, then empowering them with the tools and education they need to prevent transmission. These include bed nets and repellents to prevent transmission through mosquitoes and condoms to prevent transmission through sex. Screening, which should be conducted confidentially to avoid stigma, could also identify where community level measures such as spraying might be optimally targeted. This strategy mirrors the approach Anthony Fauci proposed for ending HIV/AIDS, for which there is also no vaccine. ${ }^{11}$

Changing behavior is difficult, which is why vaccines are often prioritized during pandemics. However, during the Ebola crisis, it was large scale behavior change that marked a turning point in the epidemic. ${ }^{12}{ }^{13}$ For Zika, people are aware of the general advice to avoid mosquitoes and practice safe sex. However, these messages are less effective when given in broad terms to large populations. People are more likely to change their behavior if they know they are infected and grasp the importance of protecting their loved ones and communities. In a Centers for Disease Prevention and Control meta-analysis, for example, high risk sexual behavior among people who were HIV positive was $68 \%$ lower among those who were aware of their diagnosis than among those who were unaware. ${ }^{14}$

Door-to-door screening is already happening in some counties of Florida, ${ }^{15}{ }^{16}$ but screening on a wider scale — as needed in Puerto Rico where one in four people may become infected ${ }^{17}$-requires a point-of-care test, ideally self administered, so people can learn their infection status. Currently, Zika is diagnosed with laboratory based methods that cannot be scaled up for screening, especially in developing countries. Even Florida, with plenty of financial resources, can perform only a few hundred tests a day, ${ }^{18}$ and some pregnant women wait six weeks for results. ${ }^{19}$

A point-of-care screening test would need to be specific enough to permit laboratory confirmation of positive results yet sensitive enough to reduce the transmission rate below one. ${ }^{20}$ Antibody or viral RNA tests are both possible but neither is perfect. Antibody tests would identify new cases during the first week of infection ${ }^{21}$ but may also detect people with past infection who are not currently viremic and therefore no longer a source of mosquito-borne transmission (though the virus remains transmissible through semen and possibly other bodily fluids for months). ${ }^{223}$ Viral RNA tests ${ }^{24}$ would identify active viremia but miss those with recent infection.

Ideally, a test would use both approaches, but, practically, since most transmission is through mosquitoes, ${ }^{25}$ whichever type is developed first should be immediately deployed. Antibody tests, likely to be faster and cheaper to develop, ${ }^{26}$ could be implemented with traditional laboratory based testing to determine whether people have active or past infection.

Recently, the US government announced a \$20m (£16m; €19m) competition for point-of-care tests for antimicrobial resistance. A similar initiative is needed for Zika. The US government has awarded contracts for companies to develop point-of-care Zika 
diagnostics, ${ }^{27-29}$ but with no accelerated or definite time frame to assure availability within the next few months-the critical timescale. If made a priority with resources to back it up, point-of-care Zika tests could be developed within months at a fraction of the cost of vaccines. ${ }^{28-31}$

In countries with even rudimentary health systems, screening could be implemented through existing clinics and community health workers, enabling rapid scale-up to areas with active transmission at minimal incremental cost. In settings where healthcare access is limited, screening could be conducted through outreach, perhaps using community based institutions such as schools and non-profit groups.

Until a Zika vaccine is available, we could mimic its effect on human mediated transmission with voluntary screening and targeted engagement and, within months, slow Zika's spread.

Competing interests: We have read and understood BMJ policy on declaration of interests and have no relevant interests to declare.

Provenance and peer review: Not commissioned; externally peer reviewed.

1 Bogoch II, Brady OJ, Kraemer MUG, et al. Potential for Zika virus introduction and transmission in resource-limited countries in Africa and the Asia-Pacific region: a modelling study. Lancet Infect Dis 2016;356:1237-45. doi:10.1016/S1473-3099(16)30270-5 pmid: 27593584.

2 Belluck P. Microcephaly found in babies of Zika-infected mothers months after birth. New York Times 2016 Nov 22. http://www.nytimes.com/2016/11/22/health/zika-microcephalybabies.html?_r=0

3 Osterholm MT. Ebola and Zika: cautionary tales. Science 2016;356:1073. doi:10.1126/ science.aai9078 pmid:27609862.

4 Miller HI. A Zika vaccine poses a number of problems. Wall Street Journal 2016 Sep 14 http://www.wsj.com/articles/a-zika-vaccine-poses-a-number-of-problems-1473889648

5 Marston HD, Lurie N, Borio LL, Fauci AS. Considerations for developing a Zika virus vaccine. N Engl J Med 2016;356:1209-12. doi:10.1056/NEJMp1607762 pmid:27682031.

6 Thomas SJ, L'Azou M, Barrett ADT, Jackson NAC. Fast-track Zika vaccine development-is it possible? N Engl J Med 2016;356:1212-6. doi:10.1056/ NEJMp1609300 pmid:27682032.

7 Thomas K. The race for a Zika vaccine. New York Times, 2016 Nov 19. http://www.nytimes. com/2016/11/20/business/testing-the-limits-of-biotech-in-the-race-for-a-zika-vaccine.html

8 Thangamani S, Huang J, Hart CE, Guzman H, Tesh RB. Vertical transmission of Zika virus in Aedes aegypti mosquitoes. Am J Trop Med Hyg 2016;356:1169-73. doi:10.4269/ ajtmh.16-0448 pmid:27573623.

9 Lessler J, Chaisson LH, Kucirka LM, et al. Assessing the global threat from Zika virus. Science 2016:356:aaf8160. doi:10.1126/science.aaf8160 pmid:27417495.

10 McNeil DG. Big success story: Sri Lanka is declared free of malaria. New York Times 2016 Sep 12. https://www.google.com/amp/mobile.nytimes.com/2016/09/13/health/srilanka-declared-free-of-malaria.amp.html

11 American Academy of Dermatology. An end to the HIV/AIDS pandemic is in sight. Summer meeting news 2016. http://aad-365.ascendeventmedia.com/2016-annual-meeting-dailies/ an-end-to-the-hivaids-pandemic-is-in-sight/
12 Onishi N. As Ebola ebbs in Africa, focus turns from death to life. New York Times 2015 Jan 31. http://www.nytimes.com/2015/02/01/world/as-ebola-ebbs-in-africa-focus-turnsfrom-death-to-life.html

13 Funk S, Knight GM, Jansen VAA. Ebola: the power of behaviour change. Nature 2014;356:492.. http://www.nature.com/nature/journal/v515/n7528/full/515492b.html. doi: 10.1038/515492b pmid:25428491.

14 Marks G, Crepaz N, Senterfitt JW, Janssen RS. Meta-analysis of high-risk sexual behaviour in persons aware and unaware they are infected with HIV in the United States. $J$ Acquir Immune Defic Syndr 2005:356:446-53. doi:10.1097/01.qai.0000151079.33935.79 pmid: 16010168.

15 Florida Department of Health. Daily Zika update, 10 Nov 2016. http://www.floridahealth. gov/newsroom/2016/11/111016-zika-update.html

16 Goldschmidt D. CDC to pregnant women: avoid another part of Miami. Cable News Network 2016 Aug 19. http://www.cnn.com/2016/08/19/health/local-transmission-of-zikavirus-confirmed-in-miami-beach/index.html

17 McNeil DG. Zika cases in Puerto Rico are skyrocketing. New York Times 2016 Jul 30. https://www.nytimes.com/2016/07/31/health/zika-virus-puerto-rico.html

18 Chang D. Zika testing gets a boost with more lab supplies and staffing. Miami Herald 2016 Sep 20. http://www.miamiherald.com/news/health-care/article102962007.html

19 Alvarez L. Pregnant women anxious as Florida's Zika test results take weeks. New York Times 2016 Sep 12. http://mobile.nytimes.com/2016/09/13/us/zika-test-delays-floridapregnant.html

20 Dhillon RS, Srikrishna D, Garry RF, Chowell G. Ebola control: rapid diagnostic testing. Lancet Infect Dis 2015;356:147-8.. doi:10.1016/S1473-3099(14)71035-7 pmid:25467648.

21 Rabe IB, Staples JE, Villanueva J, et al. MTS. Interim guidance for interpretation of Zika virus antibody test results. MMWR Morb Mortal Wkly Rep 2016;356:543-6. doi:10.15585/ mmwr.mm6521e1. pmid:27254248.

22 Barzon L, Pacenti M, Franchin E, et al. Infection dynamics in a traveler with persistent shedding of Zika virus RNA in semen for six months after returning from Haiti to Italy, January 2016. Euro Surveill 2016;356. doi:10.2807/1560-7917.ES.2016.21.32.30316.

23 Mansuy JM, Suberbielle E, Chapuy-Regaud S, et al. Zika virus in semen and spermatozoa. Lancet Infect Dis 2016;356:1106-7. doi:10.1016/S1473-3099(16)30336-X. pmid:27676340.

24 Interim guidance for Zika virus testing of urine-United States. MMWR Morb Mortal Wkly Rep 2016;356. doi:10.15585/mmwr.mm6518e1.

25 Althaus CL, Low N. How relevant is sexual transmission of Zika virus?PLoS Med 2016;356:e1002157.. doi:10.1371/journal.pmed.1002157 pmid:27780196.

26 Dhillon RS, Kelly JD, Srikrishna D, Garry RF. Overlooking the importance of immunoassays. Lancet Infect Dis 2016;356:1109-10. doi:10.1016/S1473-3099(16)303383 pmid:27676344.

27 United States Department of Health and Human Services. HHS funds development of Zika diagnostic test for use in doctors' offices. Press release, 25 Aug 2016. https://www. hhs.gov/about/news/2016/08/25/hhs-funds-development-zika-diagnostic-test-use-doctorsoffices.html

28 United States Department of Health and Human Services. HHS awards $\$ 7$ million to OraSure to speed development of Zika diagnostic test. Press release, 23 Aug 2016. https: //www.hhs.gov/about/news/2016/08/23/hhs-awards-7-million-orasure-speed-developmentzika-diagnostic-test.html\#

29 United States Department of Health and Human Services. HHS awards $\$ 5.1$ million to InBios to advance Zika diagnostic. Press release, 1 Aug 2016. https://www.hhs.gov/about/ news/2016/08/01/hhs-awards-5_1-million-inbios-advance-zika-diagnostic.html

30 Serdobova I, Kieny MP. Assembling a global vaccine development pipeline for infectious diseases in the developing world. Am J Public Health 2006;356:1554-9. doi:10.2105/ AJPH.2005.074583 pmid:16873743.

31 White House. Fact sheet: preparing for and responding to the Zika virus at home and abroad. Press release, 8 Feb 2016. https://obamawhitehouse.archives.gov/the-pressoffice/2016/02/08/fact-sheet-preparing-and-responding-zika-virus-home-and-abroad

Published by the BMJ Publishing Group Limited. For permission to use (where not already granted under a licence) please go to http://group.bmj.com/group/rights-licensing/ permissions 